Kong. Res. J. 4(1) : 148-160, 2017

ISSN 2349-2694

Kongunadu Arts and Science College, Coimbatore.

\title{
INVASIVE PLANTS - A BOON OR BANE TO THE LEPIDOPTERON FAUNA: CONSERVATION AND MANAGEMENT PLAN SUGGESTIONS
}

\author{
Arjun, C.P1,5., V.K. Anoop ${ }^{2}$, K.J. Tijo 3 , T.K. Anoopkumar ${ }^{3}$ and R. Roshnath ${ }^{4}$ \& \\ ${ }^{1}$ School of Ecological Informatics, Indian Institute of Information Technology and Management- Kerala, Trivandrum, Kerala. \\ ${ }^{2}$ Department of Zoology, Bharathiar University, Coimbatore, Tamil Nadu. \\ ${ }^{3}$ Center for Wildlife Studies, Kerala Veterinary and Animal Sciences University, Pookode, Wayanad. \\ ${ }^{4}$ Central University of Kerala, Kasargod, Kerala. ${ }^{5}$ Malabar Awareness and Rescue Centre, Kannur, Kerala.
}

\begin{abstract}
Butterfly diversity was recorded from Nov (2013) - May (2014) in Pookode region. A total number of 128 species recorded from the five families; Nymphalidae (46 species) Lycaenidae (28 species), Hesperiidae (22 species), Pieridae (17 species) and Papilionidae (15 species) respectively. During the survey invasive plant species were also recorded. There were 36 species of invasive plants from 18 families identified from the study area. More butterflies were attracted towards nectar offering invasive plants. Chromolaena odorata, Ipomea cairica, Lantana camara, Merremia vitifolia, Mikania micrantha, Mimosa diplotricha, Pennisetum polystachyon, Pteridium aquilinum, Quisqualis indica and Sphagneticola trilobata were the major invasive plants found in the Pookode region and their flower attracts butterfly for pollination. Even though nectar offered by the plants are supportive for growth, in long run these species can affect butterfly population by declining native host larval plant species for butterfly reproduction. Invasive species compete with the native flora and reduce its population. Management practices like physical, chemical and modern bio control measures could be used for eradicating of invasive plants. Wise use of invasive plants for other economical purpose such as bio-fuel, medicinal purpose, bio-pesticide and handicraft could be suggested. Successful management of invasive species are needed for conserving Lepidoptera fauna and other native biota of the area.
\end{abstract}

Keywords: Butterflies, invasive plants, host plants, management practices, conservation.

\section{INTRODUCTION}

Arthropods occupy half of earth's biodiversity (May, 1992) among these, butterflies fascinate the most. Their interaction with the ecosystem as pollinators and herbivorous are notable (Tiple et al.., 2006). They are highly sensitive to solar radiation, temperature and variations in micro habits (Thomas et al.., 1998). Anthropogenic disturbance and habitat quality variation (Kocher and Williams, 2000) reflects butterfly lifestyle, because of these reasons butterflies chose good candidate as bio-indicators to access habitat fragmentation, soil degradation and water pollution (Kehimkar, 2000). The Indian subcontinent hosts about 1,504 species of butterflies, and Western Ghat hosts 351species of butterflies (Smetacek, 1992; Gaonkar, 1996; Kunte, 2009; Roy et al., 2010and Tiple, 2011). The amount of the Indian butterflies is one fifth of the world butterflies (Kunte, 2000).The diversity and distribution of a particular species of butterfly is dependent not only on the geography of the area and the ability of the species to move around within it, but also on the ecological demands of the species (Khan et al., 2011).
Many of the butterflies are strictly seasonal and prefer particular set of habitat (Kunte, 1997). Butterflies and plants have intimate relationship, as food source and as larval host plants. (Feltwell, 1986). Butterfly diversity and abundance would be more in that vegetation which offers these. Invasion of invasive species were noted during the survey. Showy flowers of invasive species may draw pollinators (Armbruster and Herzig, 1984). This reduces the reproductive capacity of native plants (Brown 2002).

\section{METHODOLOGY}

Population survey of Lepidoptera were conducted monthly once between Nov (2013) May (2014) in the campus using line pollard walk method (Pollard, 1977). Survey was conducted from 8.00AM to $11.00 \mathrm{AM}$ during the peak activity of butterflies. Species were identified through direct observation, photographs, eggs, pupa and larval forms with the help of field guides (Wynder-Blyth, 1957; K. Kunte, 2000; Kehimkar, 2008; George M, 2011) 


\subsection{Study area}

Pookode located in Vythiri Panjayath which is southern part of Wayanad District. Pookode has mixed vegetative types including grassland, moist deciduous forest, semi-evergreen forest, plantations, rocky areas and riverine streams. Altitude varies 745-930 meter from the sea level and average temperature is about $25.75^{\circ} \mathrm{C}$ and annual rainfall is $5318 \mathrm{~mm}$.

Study area hosts several types of vegetation, semi-evergreen patches were found adjacent to plantation (mainly coffee and tea) with large trees in between. Invasive species like Chromolaena odorata and Mikania micrantha were also observed along with the other native vegetation. Scrub land consists of open hilly terrains along with grassland habitat towards the summit of the Pookode region. Grasses such as Cymbopogon citrates and trees like Careya arborea dominate the habitat. Lantana camara and Chromolaena odorata are the dominating invasive species in the scrub land habitat. Riparian habitats run along the streamlets of Vythiri River towards the base of the Pookode where reeds are dominating the vegetation. Sphagneticola trilobata were the major invasive vegetation in riverine habitat.

\section{RESULTS AND DISCUSSION}

A total number of 128 species (Table.1) recorded from the five families. Nymphalidae (46 species) is the most abundant and Papilionidae (15 species) is the least abundant. Lycaenidae (28 species), Hesperidia (22 species), Pieridae (17 species) recorded respectively (Fig:1).

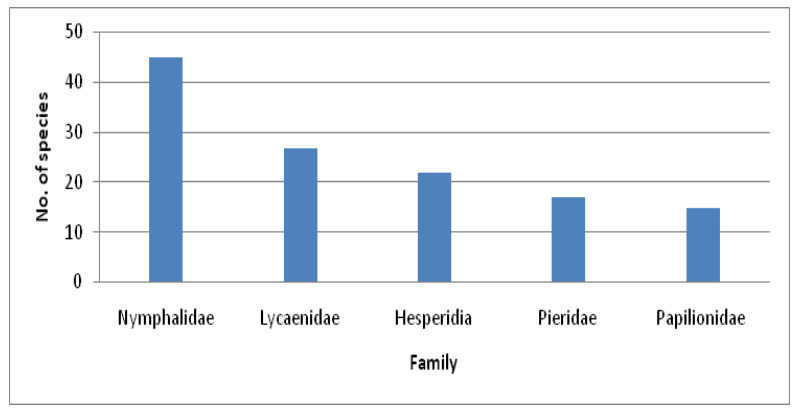

Fig. 1: Family wise abundance in the butterfly species in the Pookode region.

The Pookode region host rich Lepidoptera diversity and abundance. Many of the species recorded in the region are of conservational importance. Fourteen species belongs to scheduled list of Indian Wildlife protection act 1972 Scheduled I; -Atrophaneura hector, Papilio liomedon, Hypolimnas misippus, Scheduled II; Papilio Buddha,
Kallima horsfieldi, Euthalia aconthea, Libythea lepita, Tanaecia lepidea, Discophora lepida, Appias albino, Spindasis lohita, Lampides boeticus, Scheduled IV;Prioneris sita, Tarucus ananda. 10 species were endemic to the Western Ghats they are Troides minos, Kallima horsfieldi, Idea malabarica, Curetis siva, Aeromachus pygmaeus, Zipaetis saitis (Western Ghats and SriLanka), Papilio buddha, Papilio liomedon, Discophora lepida, Discophora lepida, Mycalesis patina. Occurrence of Blue Nawab (Polyura schreiber) was a rare record in the state. Hence the area must be conserved for promoting Lepidoptera diversity.

Threats faced by butterflies in the area are urbanization and construction activities leading to habitat fragmentation that force butterflies to settle in narrow habitats causing population decline. Cattle grazing were another threat in the area where larval host plants are grazed by cattle which affect butterfly population (Runquist, 2011). But threats due to invasive plant species were considered higher than the others.

There is an intimate relationship between butterflies and plants (Feltwell, 1986), butterflies needs plants as food source and as larval host plants where as plants need these insects for pollination

Butterflies were found to feed on nectars of invasive plant species like Chromolaena odorata, Ipomea cairica, Lantana camara, Merremia vitifolia, Mikania micrantha, Mimosa diplotricha, Pennisetum polystachyon, Pteridium aquilinum, Quisqualis indica and Sphagneticola trilobata etc. Most of these plants provide nectar throughout the year (Nimbalkar et al., 2011) to the butterflies but none of these invasive plants host butterfly larval forms of single species of butterflies.

Egg laying of Acacia Blue butterfly were observed in Mimosa invasia during the survey. Acheronita styx (Death's headed hawk moth) laying egg in Lantana camara was reported by Kehimkar, 2000, but prefer less. A total 36 species of invasive plants recorded (Table: 2) from the study area among the plants Chromolaena odorata, Clidemia hirta, Lantana camara, Leucaena leucocephala and Mikania micrantha enlisted in IUCN world 100 worst invaders because of its ability to dominate and devastate native biota (Lowe et al.. 2000).

Invasive plants are second largest threat to the biodiversity after habitat destruction (Enserink, 1999). Many of the invasive species become invades and explore higher than in their native regions. (D'Antonio and Vitousek 1992; Ridenour and 
Callaway 2001; Louda et al., 2003). These invasive species can cause large decreases in the abundances of native species (Braithwaite et al.. 1989; Memmott et al.. 2000; Grigulis et al.. 2001). Invasive species compete with native species in different ways including competition for nutrients (Wardle et al., 1994), Water (Delph 1986), Light (Grace and Wetzel 1981, 1982, Weihe and Neely 1997), space (Agren and Fagerstrdm 1980, Newsome and Noble 1986), competitive release, and predatory release (Rodriguez, 2006). These competitions may reduce the ability of native species to maintain or increase population size (Huenneke and Thomson 1995).

Beyond such vegetative competition, competition for pollinator services by invasive plants may also reduce the reproductive capacity of native plants (Brown, 2002). More butterflies were observed in the areas where high populations of Lantana camara, Mikania micarantaand C. odorata were present. An experimental study showed that butterflies are more attracted to amino acid contacting nectar provided by L. camara. (Alm, 1990). Some substances produced by the allelopathic effect of invasive species like Lantana camara, (Sharma et al., 2007., Kumbhar and Patel 2013 Mishra 2013, 2014, Gantayet et al., 2014.). C. odorata and Mikania micaranta (Sahid, 2014)are well documented Organic substances produce by plants as secondary metabolites such as alkaloids, Phenoics , flavonoids, Terpenoids and Glucosinolates are known to inhibit the seed germination, growth and development of other species (Rice,1974; Day et al..,2003)

Showy invasive species may draw pollinators away from native species, decreasing visit quantity (Free, 1968, Waser, 1978a, Gross and Werner 1983, Armbruster and Herzig, 1984) hence pollinations by butterflies and other insects were more in invasive plants thereby improving their propagation. Research shows native species suffers significantly reduced seed set in the presence of an aggressive invading congener when the species share the same kind of pollinators (Brown, 2002).

\subsection{Major invasive plants and its invasion in the study area}

Lantana was the major invasive plant in the study area. It was introduced as an ornamental plan into many tropical and subtropical world from its native south and Central America during nineteenth and early twentieth century (Mack et al. 2000). Thereafter like all other invasive species Lantana had established causing threat to biodiversity (Hiremath and Sundaram., 2005). It is having high regeneration capacity and can also survive in degraded soils (Bhatt et al., 1994; Rawat et al., 1994). Lantana is exceedingly efficient at nutrient uptake and use, enabling it to grow on highly impoverished soils (Bhatt et al., 1994; Rawat et al., 1994) Lantana may be favored by disturbances such as fire and grazing (Duggin and Gentle 1998; Gentle and Duggin, 1998).

Another important invasive species in the study area was Chromolaena odorata (L.) (Asteraceae). Florets of these plants attract butterflies and form an important nectar source for adult butterflies (Lakshmi and Raju, 2011). A study in Bangladesh showed 55 species of butterflies use this plant as a source of nectar (Shihan and Kabir, 2015). Arrangement of florets provide convenient landing place for butterflies and a butterfly can probe several flowers at a time in single visit (Lakshmi and Raju, 2011). Hexose rich sugar and high amino acid concentration in Asteraceae plants can attract butterflies and other pollinators (Baker and Baker 1983., Galetto and Bernardello, 2003).

Clidemia hirta, commonly called Koster's Curse which is a native Tropical America listed under IUCN 100 worst invasive species was another invasive species found during the survey. They are densely branched shrub up to $5 \mathrm{~m}$ tall, normally between 0.5 and $3 \mathrm{~m}$. C. hirta have pinkish white flowers and dark blue berries. It is an aggressive colonizer which can produce 500 berries which contain 100 seeds per fruit.

Mikania micrantha one among the worst invasive plants of the World which belongs to the family Asteraceae (Lowe et al., 2000). There are of 250 species in this genus Mikania however 4 species are known to be invasive. Among these Mikania micrantha is the only invasive plant in Asia-Pacific region. This is an invading creeper can grow $8-9 \mathrm{~cm}$ a day and able to create a thick envelope over the native biota eventually devastate native plants by blocking sunlight and its allelopathic effect. Flowers are good nectar source for many insects including butterflies which accelerate the pollination and spreading of the Mikania.

\subsection{Removal and alternative uses of Invasive plant species}

Past hundred years about 40 species of pathogens and insects tried on Lantana as bio control agents but none of them can acquire significant effect on Lantana (Sankaran et al., 2010). 
Here the importance of biofuel production from Latana camara. Bioethanol property of Lantana camera (Ramesh et al., 2010) and its low cost production were identified. An industrial level production of biofuel can make significant control over the Lantana. Further research are needed to identify similar characteristics of other invasive plants.

A management method that involves manual or mechanical means to remove or alter growing conditions of invasive plants are termed physical methods. This method prevent invasive plant establishment, as when soils are frequently hoed or tilled to disturb the soil seed bank and uproot seedlings (Radosevich et al., 1997). After any physical treatment, it is important to inspect tools and equipment and to safe disposal (burning) of invasive plant to prevent propagation to new sites (Holloran et al., 2004). Physical removal or destruction of invasive plants can often be the first, simplest, and most cost effective response to a small new population (Venner, 2006).

Another method involves use of Chemical herbicides to manage invasive plants. Herbicides can efficiently and effectively suppress or kill unwanted plants but should be used judiciously, safely, and in a way that minimizes adverse effects on non-target resources. (D'Antonio et al., 2004)
Biocontrol was a new technological approach towards irradiation of invasive plants. Biological control (or biocontrol) reunites invasive plants with their enemies to restore natural controls and reduce dominance of invasive plants within the plant community. Any plant populations are regulated by their environment and the influence of natural enemies (Crawley 1997). Since no potential enemies are present for invasive species, they flourish in the invaded area. Absence of natural enemies contributes to the invasiveness of some nonnative plants (Keane and Crawley, 2002). Feeding of Lantana leaves by Death faced hawk moth larvae (Acheronita styx) is reported (Kehimkar, 2000 ) which can be used as natural predator of the invasive species. Insect like Teleonemia scrupulosa and fungus pathogens Prospodium tuberculatum can create dominance over Lantana in some places (Sankaran et al., 2010). The strong shoots of Lantana can be used for making handicrafts and furniture. A combined effort of bio-control, chemo-control and mechanical control measures is the best method to devastate Lantana of Pookode region.

Importing of Layothrips mikania from the Tridnad failed to adapt with the climatic condition of Solomon Islands and Malaysia against Mikania micrantha, but the fungal pathogens Paksinia spegastini can create serious effect on Mikania. This pathogens can creates disease only to the Mikania is another advantage (Sankaran et al., 2010).

Table 1. List of Butterflies species recorded in the survey conducted in Pookode region.

\begin{tabular}{|c|c|c|c|c|c|}
\hline $\begin{array}{c}\text { S. } \\
\text { No. }\end{array}$ & Common name & Scientific name & Status & $\begin{array}{c}\text { Wildlife } \\
\text { Protection } \\
\text { Act } 1972\end{array}$ & $\begin{array}{c}\text { Western } \\
\text { ghat } \\
\text { endemics }\end{array}$ \\
\hline
\end{tabular}

Papilionodae (Tailed butterflies)

$\begin{array}{ll}1 & \text { BLUE MORMON } \\ 2 & \text { COMMON BLUEBOTTLE } \\ 3 & \text { COMMON JAY } \\ 4 & \text { COMMON MORMON } \\ 5 & \text { COMMON MIME } \\ 6 & \text { COMMON ROSE } \\ 7 & \text { CRIMSON ROSE } \\ 8 & \text { LIME BUTTERFLY } \\ 9 & \text { PARIS PEACOCK } \\ 10 & \text { RED HELEN } \\ 11 & \text { MALABAR BANDED }\end{array}$

Papilio polymnestor (Cramer)

Graphium sarpedon (Linnaeus)

Graphium doson (C. and R. Felder)

Papilio polytes (Linnaeus)

Chilasa clytia (Linnaeus)

Atrophaneura aristolochiae (Fabricius)

Atrophaneura hector (Linnaeus)

S1

Papilio demoleus (Linnaeus)

Papilio paris (Linnaeus)

Papilio helenus (Linnaeus)

Papilio buddha (Westwood) 
Papilio liomedon (Moore)

Atrophaneura pandiyana (Moore)

$\mathrm{R}$

Troides minos (Cramer)

Graphium agamemnon (Linnaeus)

Nymphalidae (Brushfooted butterflies)

BAMBOO TREEBROWN

BLACK PRINCE

BLUE NAWAB

SOUTH INDIAN BLUE
OAKLEAF

BLUE ADMIRAL

BLUE PANSY

BLUE TIGER

CHOCOLATE PANSY

CLIPPER

COMMON BARON

COMMON BEAK

COMMON BUSHBROWN

COMMON CASTOR

COMMON EVENING BROWN

COMMON FIVERING

COMMON FOURRING

COMMON INDIAN CROW

COMMON LASCAR

COMMON MAP

COMMON LEOPARD

COMMON NAWAB

COMMON PALMFLY

COMMON SAILER

COMMON SERGEANT

COMMON TREEBROWN

CRUISER

DANAID EGGFLY

DARK BLUE TIGER

DARK EVENING BROWN

GLADEYE BUSHBROWN
Lethe europa (Fabricius)

Rohana parisatis (Westwood) R R

Polyura schreiber (Godart) R

Kallima horsfieldi (Kollar)

$\mathrm{R}$

S2 WE

Kaniska canace (Linnaeus)

Junonia orithiya (Linnaeus)

Tirumala limniace (Cramer)

Junonia iphita (Cramer)

Parthenos sylvia (Cramer)

Euthalia aconthea (Cramer)

S2

Libythea lepita (Moore)

S2

Mycalesis perseus (Fabricius)

Ariadne merione (Cramer)

Melanitis leda (Linnaeus)

Ypthima baldus (Fabricius)

Ypthima huebneri (Kirby)

Euploea core (Cramer)

Pantoporia hordonia (Stoll)

Cyrestis thyodamas (Boisduval)

Phalanta phalantha (Drury)

Polyura athamas (Drury)

Elymnias hypermenstra (Lennaeus)

Neptis hylas (Linnaeus)

Athyma perius (Linnaeus)

Lethe rohria (Fabricius)

Vindula erota (Fabricius)

$\mathrm{R}$

Hypolimnas misippus (Linnaeus)

S1

Western

Ghats and Sri Lanka 


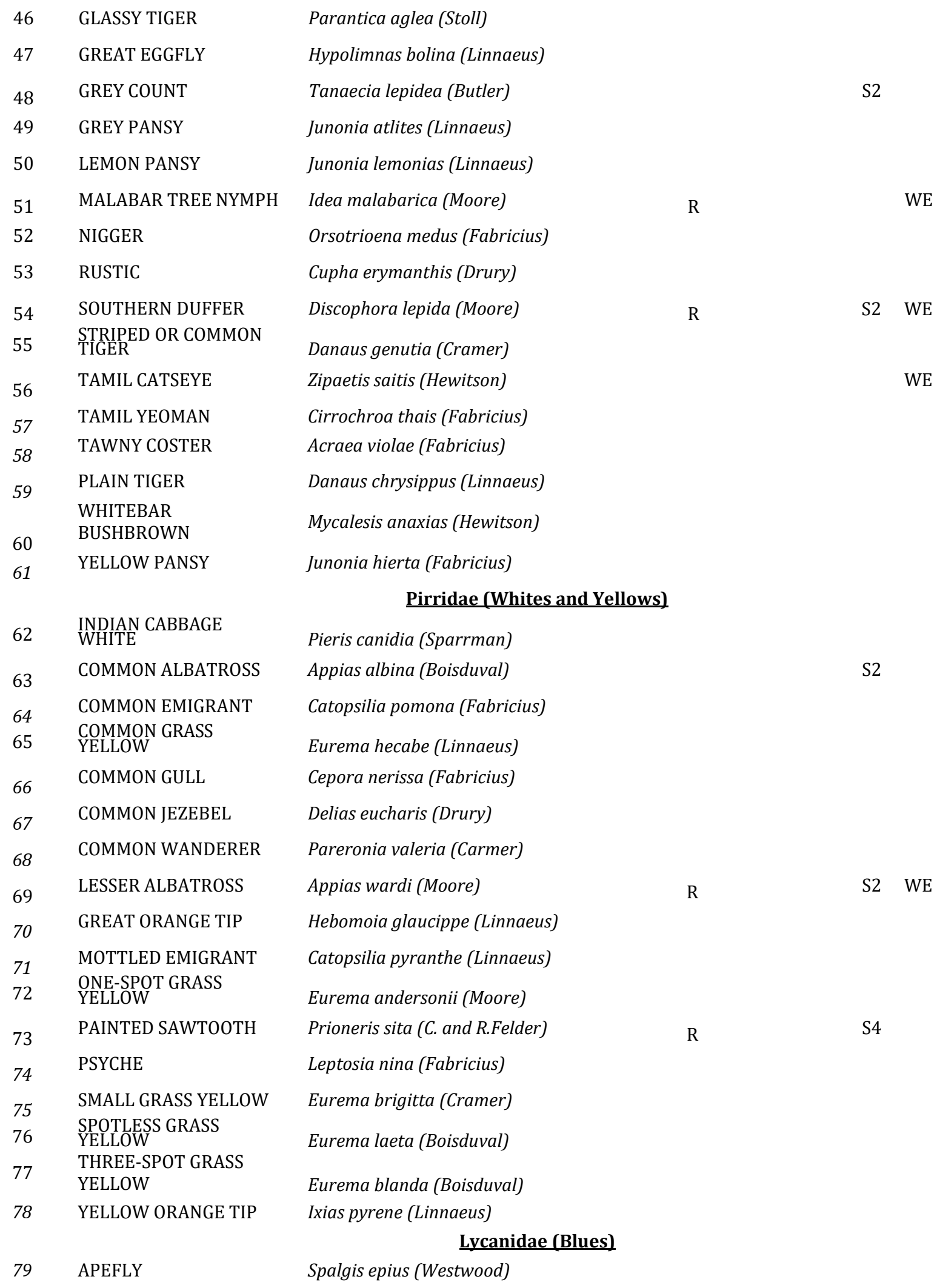




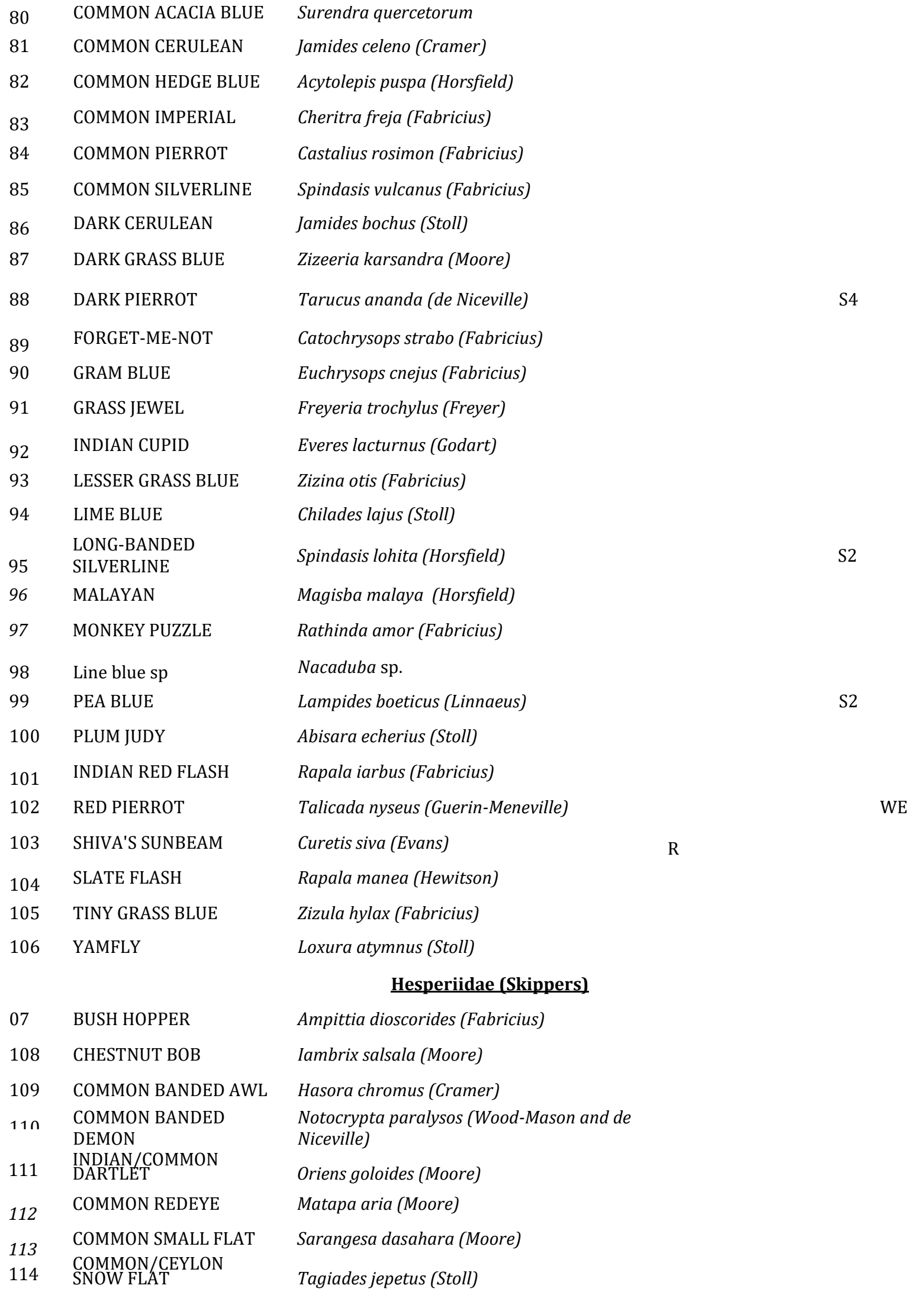




\begin{tabular}{|c|c|c|c|}
\hline 115 & $\begin{array}{l}\text { COMMON SPOTTED } \\
\text { FLAT }\end{array}$ & Celaenorrhinus leucocera (Kollar) & \\
\hline 116 & COON & Sancus fuligo (Marbille) & \\
\hline 117 & FULVOUS PIED FLAT & Psuedocoladenia dan (Fabricius) & \\
\hline 118 & GRASS DEMON & Udaspes folus (Cramer) & \\
\hline 119 & INDIAN PALM BOB & Suastus gremius (Fabricius) & \\
\hline 120 & $\begin{array}{l}\text { INDIAN } \\
\text { GRIZZLED/INDIAN } \\
\text { SKIPPER }\end{array}$ & Spialia galba (Fabricius) & \\
\hline 121 & DARK PALM DART & Telicota ancilla (Herrich-Schaffer) & \\
\hline $\begin{array}{l}122 \\
123\end{array}$ & $\begin{array}{l}\text { Unknown Dart } \\
\text { PYGMY GRASS-/SCRUB- } \\
\text { HOPPER }\end{array}$ & $\begin{array}{l}\text { Potanthus sp. } \\
\text { Aeromachus pygmaeus (Fabricius) }\end{array}$ & WE \\
\hline 124 & RESTRICTED DEMON & Notocrypta curvifascia (C. R. Felder) & \\
\hline 125 & RICE SWIFT & Borbo cinnara (Wallace) & \\
\hline 126 & $\begin{array}{l}\text { DARK SMALL-BRANDED } \\
\text { SWIFT }\end{array}$ & Pelopidas mathias (Fabricius) & \\
\hline 127 & BROWN AWL & Badamia exclamationis (Fabricius) & \\
\hline 128 & TAMIL GRASS DART & Taractrocera ceramas (Hewitson) & \\
\hline
\end{tabular}

S1-Scheduled I, Wildlife Protection Act 1972, S2-Scheduled II WPA 1972, S4- Scheduled IV WPA 1972, R- Rare, WE- Westerm Ghat Endemic

Table 2. List of invasive plants recorded in study area.

\begin{tabular}{|c|c|c|c|c|c|}
\hline $\begin{array}{c}\text { Si } \\
\text { NO }\end{array}$ & Family & Scientific Name & Common Name & Native Place & $\begin{array}{c}\text { Risk } \\
\text { Level }\end{array}$ \\
\hline 1 & Asteraceae & $\begin{array}{l}\text { Ageratina } \\
\text { adenophore }\end{array}$ & Crofton Weed & Central America & $\begin{array}{l}\text { Medium } \\
\text { Risk }\end{array}$ \\
\hline 2 & Asteraceae & $\begin{array}{l}\text { Ageratum } \\
\text { conyzoides }\end{array}$ & Goat Weed & Central America & Low Risk \\
\hline 3 & Amaranthaceae & $\begin{array}{l}\text { Alternanthera } \\
\text { brasiliana }\end{array}$ & Red calico Plant & Latin America & Low Risk \\
\hline 4 & Amaranthaceae & $\begin{array}{l}\text { Amaranthus } \\
\text { spinosus }\end{array}$ & $\begin{array}{c}\text { Prickly } \\
\text { amaranthus }\end{array}$ & Central America & Low Risk \\
\hline 5 & Iridacea & Aristea ecklonii & Blue Star & Africa & No risk \\
\hline 6 & Asclepiadaceae & $\begin{array}{l}\text { Asclipias } \\
\text { curassavica }\end{array}$ & Blood flower & Tropical America & No risk \\
\hline 7 & Asteraceae & Bidens sulphurea & Sulphus cosmos & North America and Africa & No risk \\
\hline 8 & Solanaceae & $\begin{array}{l}\text { Brugmansia } \\
\text { arborea }\end{array}$ & $\begin{array}{l}\text { White angel } \\
\text { trumpet }\end{array}$ & South America & $\begin{array}{l}\text { Medium } \\
\text { Risk }\end{array}$ \\
\hline 9 & Solanaceae & $\begin{array}{l}\text { Brugmansia } \\
\text { Suaveolens }\end{array}$ & Angel's Trumpet & $\begin{array}{l}\text { Tropical and Subtropical } \\
\text { America }\end{array}$ & No risk \\
\hline 10 & Apocynaceae & $\begin{array}{l}\text { Catharanthus } \\
\text { roseus }\end{array}$ & Periwinkle & Madagascar & No risk \\
\hline 11 & Asteraceae & $\begin{array}{l}\text { Centratherum } \\
\text { intermedium }\end{array}$ & $\begin{array}{l}\text { Brazilian Button } \\
\text { Flower }\end{array}$ & South America & No risk \\
\hline 12 & Asteraceae & $\begin{array}{l}\text { Chromolaena } \\
\text { odorata }\end{array}$ & Siam weed & Tropical America & High Risk \\
\hline 13 & Melanostomaceae & Clidemia hirta & Koster's curse & $\begin{array}{c}\text { Tropical and Central } \\
\text { America }\end{array}$ & Low Risk \\
\hline 14 & Verbenaceae & Duranta erecta & Duranta curse & South America & No risk \\
\hline
\end{tabular}




\begin{tabular}{|c|c|c|c|c|c|}
\hline 15 & Acanthaceae & $\begin{array}{l}\text { Hypoestes } \\
\text { sanguinolenta }\end{array}$ & Measles plant & Madagascar & $\begin{array}{l}\text { Medium } \\
\text { Risk }\end{array}$ \\
\hline 16 & Lamiacea & $\begin{array}{l}\text { Hyptis } \\
\text { suavelolens }\end{array}$ & Pignut & Tropical America & $\begin{array}{l}\text { Medium } \\
\text { Risk }\end{array}$ \\
\hline 17 & Convolvulaceae & Ipomea cairica & Railway creeper & Tropical Africa and Asia & High Risk \\
\hline 18 & Verbenaceae & Lantana camara & Lantana & Central and South America & High Risk \\
\hline 19 & Mimosaceae & $\begin{array}{l}\text { Leucaena } \\
\text { leucocephala }\end{array}$ & Lead tree & Tropical America & Low Risk \\
\hline 20 & Onagraceae & $\begin{array}{l}\text { Ludwigia } \\
\text { peruviana }\end{array}$ & Prim rose tree & North America & $\begin{array}{l}\text { Medium } \\
\text { Rișk }\end{array}$ \\
\hline 21 & Rhamnaceae & Maesopsis eminii & Umbrella tree & West and Central Africa & $\begin{array}{l}\text { Medium } \\
\text { Risk }\end{array}$ \\
\hline 22 & Convolvulaceae & $\begin{array}{l}\text { Merremia } \\
\text { vitifolia }\end{array}$ & $\begin{array}{l}\text { Grape leaf wood } \\
\text { rose }\end{array}$ & Indo Maleshya and China & High Risk \\
\hline 23 & Asteraceae & $\begin{array}{l}\text { Mikania } \\
\text { micrantha }\end{array}$ & Mile-a-minute & South America & High Risk \\
\hline 24 & Mimosaceae & $\begin{array}{l}\text { Mimosa } \\
\text { diplotricha }\end{array}$ & $\begin{array}{l}\text { Giant sensitive } \\
\text { plant }\end{array}$ & Tropical America & High Risk \\
\hline 25 & Mimosaceae & Mimosa pudica & Touch-Me-Not & South America & Low Risk \\
\hline 26 & Asteraceae & $\begin{array}{l}\text { Parthenium } \\
\text { hysterophorus }\end{array}$ & Congress grass & North and South America & Medium \\
\hline 27 & Poaceae & $\begin{array}{l}\text { Pennisetum } \\
\text { pedicellutum }\end{array}$ & Kyasuwa grass & Africa and Asia & $\begin{array}{l}\text { Medium } \\
\text { Risk }\end{array}$ \\
\hline 28 & Poaceae & $\begin{array}{l}\text { Pennisetum } \\
\text { polystachyon }\end{array}$ & Mission grass & Tropical Africa & High Risk \\
\hline 29 & Solanaceae & $\begin{array}{l}\text { Physalis } \\
\text { angulata } \\
\text { Pteridium }\end{array}$ & Sunberry & $\begin{array}{c}\text { Tropical Africa, Asia, } \\
\text { Australia }\end{array}$ & No Risk \\
\hline 30 & Dennstaedticeae & $\begin{array}{l}\text { Pterialum } \\
\text { aquilinum }\end{array}$ & Broken fern & Tropical America & High Risk \\
\hline 31 & Combretaceae & Quisqualis indica & Burma creeper & Mynamar & High Risk \\
\hline 32 & Ceasalpiniaceae & occidentalis & Coffee senna & South America & $\begin{array}{l}\text { Low Risk } \\
\text { Medium }\end{array}$ \\
\hline 33 & Ceasalpiniaceae & Senna tora & Sickle senna & South America & $\begin{array}{l}\text { Medium } \\
\text { Risk }\end{array}$ \\
\hline 34 & Asteraceae & $\begin{array}{l}\text { Sphagneticola } \\
\text { trilobata }\end{array}$ & Singapore Daisy & Tropical America & High Risk \\
\hline 35 & Asteraceae & $\begin{array}{l}\text { Tithonia } \\
\text { diversiflora }\end{array}$ & Mexican sunflower & $\begin{array}{c}\text { Mexico and Central } \\
\text { America }\end{array}$ & $\begin{array}{l}\text { Medium } \\
\text { Risk }\end{array}$ \\
\hline 36 & Asteraceae & procumbens & Coat button & Tropical America & No risk \\
\hline
\end{tabular}

\subsection{Bio pesticides and Fertilizer}

Bio pesticide property of Chromolaena odorata, Lantana camara, plants were already identified. Industrial base production of bio pesticide from these plants may decrease its invasion and provide job to the communities depend on this.

It was reported that the compost of Mikania gives better yields in the paddy fields of Mizoram (Sankaran et al., 2010). Small scale industries could take up such initiatives. Hence removal of invasive weeds for the production of such products can lead to biodiversity conservation and also enhance economy.

\subsection{Management}

The diversity of butterflies for particular habitats is associated with the availability of larval host plants and adult nectar plants (Shihan and Kabir, 2015). Increase in nectar plant and decline in larval host plants may adversely affect butterfly population.

According to Rejmanek, 2003, three management objectives were suggested to weed 
control; they are prevention/ exclusion, early detection, rapid assessment and control/ eradiation. No assessment in the percentage cover of invasive plants was done in the area. Knowledge about the status and range of invasive plant species would help in better management plants. Proper and systematic scientific studies would bring out effective ways to control invasive plants.

Use of Lantana as fencing and ornamental flower in garden should be discouraged. Lantana plants should not be planted in and around the crop fields (Gantayet et al., 2014). Clearing lands with invasive plants, continual follow-up treatment to remove roots and seedlings would be effective way to control invasive plants (Gantayet et al., 2014)

\section{ACKNOWLEDGEMENT}

We are greatfully to Dr. George Chandy (Director in charge, Centre for Wildlife Studies, CVandAS, Pookode, Wayanad) for the encouragement and Dr. Kalesh Sadasivan (Trivandrum Natural History and Society) for identifying complex species.

Some observation on nectar feeding of butterflies from invasive plants of Pookode region

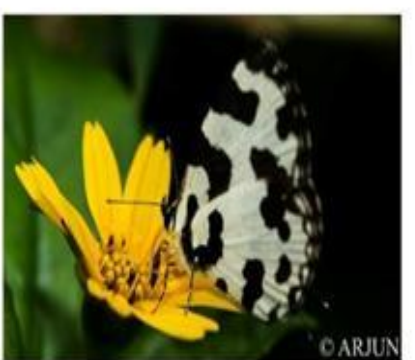

Angled Pierrot feeding nectar from Sphagneticola trilobata

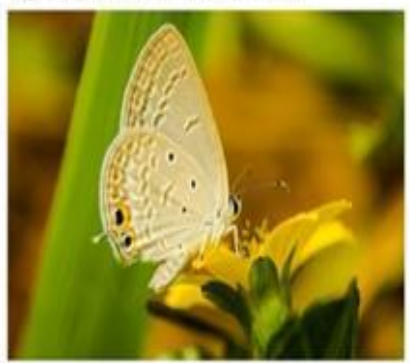

Gram blue feeding nectar from Sphagneticola trilobata

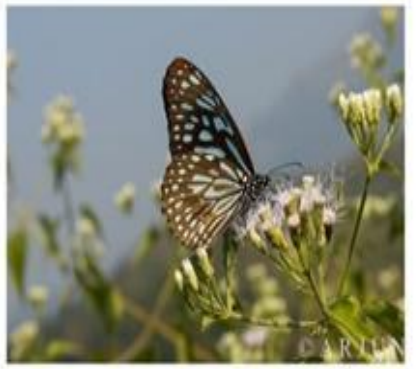

Dark Blue Tiger feeds nectar from C. odorata

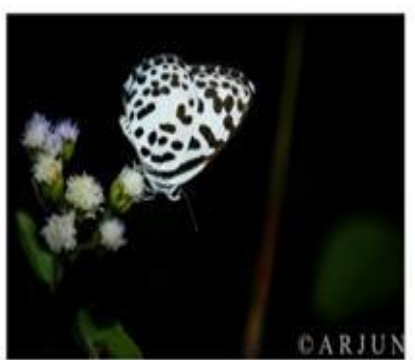

Common pierrot feeding nectar from Chromolaena odorata

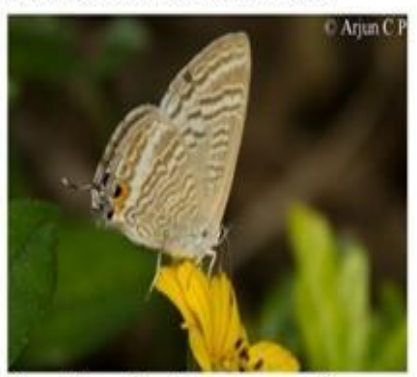

Pea Blue feeding necatar from Sphagneticola trilobata

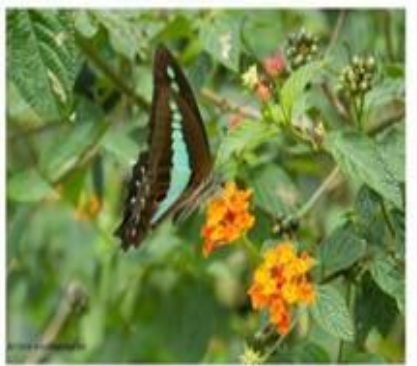

Common Bluebottle feeding nec tar from L. camara

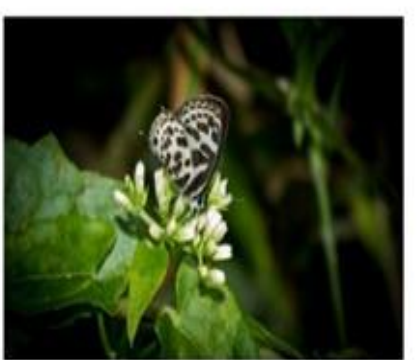

Dark Pierrot feeding nectar from Mikania micrantha

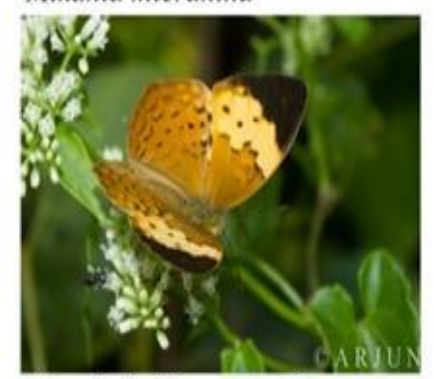

Rustic feeding nectar from M. micrantha

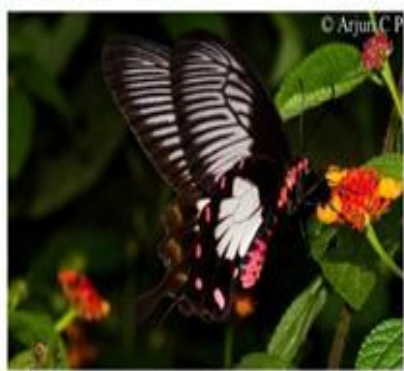

Malabar Rose feeding nectar from Lamtana camara 


\section{REFERENCES}

Agren, G.I. and T. Fagerstrom, (1980). Increased or decreased separation of flowering time? The joint effect of competition for space and pollination in plants. Oikos. 35:161- 164.

Alm, J., E. Thomas, Ohnmeiss, Janet Lanza, Lauren Vriesenga, (1990). Preference of cabbage white butterflies and honey bees for nectar that contains amino acids. Oecologia. 84(1). 53-57pp.

Armbruster, W.S., and A.L. Herzig, (1984). Partitioning and sharing of pollinators by four sympatric species of Dalechampia (Euphorbiaceae) in Panama. Ann. Missouri Botanical Garden. 71:1-16.

Baker, H.G. and I. Baker, (1983). Floral nectar sugar constituents in relation to pollinator type. In: Jones CE, Little RJ (eds.). Handbook of Experimental Pollination Biology. Scientific and Academic Editions. New York. 117-141.

Bhatt, Y.D., Y.S. Rawat and S.P. Singh, (1994). Changes in ecosystem functioning after replacement of forest by Lantana shrubland in Kumaon Himalaya. J. Veg. Sci. 5: 67-70.

Braithwaite, R.W., W.M. Lonsdale, and J.A. Estbergs, (1989). Alien vegetation and native biota in tropical Australia: the impact of Mimosa pigra. Biol. Cons. 48: 189-210.

Brown, Beverly, J., Mitchell, J. Randall and S.A. Graham, (2002). Competition for pollination between an invasive species (Purple Loosestrife) and a Native Congener. Department of Biol. 26p.

Crawley, M.J. (1997). Plant-herbivore dynamics. Plant Ecol. Crawley MF, Eds. Malden (MA): Blackwell Science. 401-474.

D'Antonio, C.M., N.E. Jackson, C.C. Horvitz and R. Hedberg, (2004). Invasive plants in wildland ecosystems: merging the study of invasion processes with management needs. Frontiers in Ecology and the Environment 10(2): 513-521.

D'Antonio, C.M. and P.M. Vitousek, (1992). Biological invasion by exotic grasses, the grass/fire cycle and global change. Ann. Rev. Ecol. Systemat. 23: 63-87.

Day, M.D, Wiley C.J, Playford, J. and Zalucki, M.P. 2003. Lantana: current management status and future prospects. (Australian Centre for International Agricultural Research: Canberra).
Delph, L.F. (1986). Factors regulating fruit and seed production in the desert annual Lesquerella gordonii. Oecologia. 69:471-476.

Duggin, J.A. and C.B. Gentle (1998). Experimental evidence on the importance of disturbance intensity for invasion of Lantana camara in dry rain forest open forest ecotones in north-east NSW, Australia. Forest Ecol. Manag. 109:279292.

Enserink, M. (1999). Biological invaders sweep in. Sci. 285: 1834-1836.

Feltwell, J. (1986). The Natural History of Butterflies. Groom Helem Ltd., Provident House, Bureel Row, Beckenham Kent BR3 1AT, 133pp.

Free, J.B. (1968). The flower constancy of bumblebees. J. Ani. Ecol. 39: 395-402.

Galetto, G. Land Bernardello, (2003). Nectar sugar composition in angiosperms from Chaco and Patagonia (Argentina): an animal visitor's matter? Pl. Systemat. Evol. 238: 69-86.

Gentle, C.B. and J.A. Duggin. (1998). Interference of Choricarpia leptopetala by Lantana camara with nutrient enrichment in mesic forests on the Central Coast of NSW. Pl. Ecol. 136: 205-211.

George, M.A. (2011). Handbook on the Butterlies of Nilgiri Biosphere. KFRI Research Report. 218p

Grace, J.B. and R.G. Wetzel. (1981). Habitat partitioning and competitive displacement in cattails (Typha): experimental field studies. Am. Natur. 118: 463-474.

Grace, J.B., and R.G. Wetzel, (1982). Niche differentiation between two rhizomatous plant species: Typha latifolia and Typha angustifolia. Canad. J. Bot. 60: 46-57.

Grigulis, K., A.W. Sheppard, J.E. Ash and R.H. Groves, (2001). The comparative demography of the pasture weed Echium plantagineumbetween its native and invaded ranges. J. Appl. Ecol. 38: 281-290.

Groves, H. and J.J. Burdon, (1986). Ecology of biological invasions. Cambridge University Press, Cambridge, UK.

Hegde, R., S. Suryaprakash, L. Achoth and K.S. Bawa. (1996). Extraction of non-timber forest products in the forests of the Biligiri Rangan Hills, India. Contribution to rural incomes. Econ. Bot. 50: 243-251. 
Hiremath, A.J., and B. Sundaram, (2005). The FireLantana Cycle Hypothesis in Indian Forests. Conservat. Soc. 3: 26-42

Holloran, P., A. Mackenzie, S. Farrell and D. Johnson, (2004). The Weed Workers' Handbook. Berkeley (CA): The Watershed Project and California Invasive Plant Council. 128 p.

Huenneke, L.F, and J.K. Thomson, (1995). Potential interference between a threatened endemic thistle and an invasive nonnative plant. Cons. Biol. 9: 416-425.

Keane, R.M. and M.J. Crawley (2002). Exotic plant invasions and the enemy release hypothesis. Trends in Ecol. Evol. 17(4):164-170.

Kehimkar, I. (2008). The book of Indian butterflies. Bombay Natural History Society. Oxford University Press. 497pp.

Kumbhar, B.A. and G.R. Patel, (2013). Phototoxic effect of lantana on hypocotyls and radical growth of some crop of pattern. Int. J. Integrated Inn. Tech. 2(6): 8-11.

Kunte, K. (2000). Butterflies of Peninsular India. Indian Academy of Sciences (Bangalore) and Universities Press (Hyderabad), 254pp

Louda, S.M., R.W. Pemberton, M.T. Johnson and P.A. Follett, (2003). Non-target effects: the Achilles heel of biological control? Ann. Rev. Entomol. 48: 365-396.

Lowe, S., M. Browne, S. Boudjelas and M. De Poorter, (2004). Hundred of the World's Worst Invasive Alien Species: A Selection from the Global Invasive Species Database. Invasive Species Specialist Group of the IUCN-World Conservation Union.

Mack, R.N., D. Simberloff, W.M. Lonsdale, H. Evans, M. Clout and F.A. Bazzaz, (2000). Biotic invasions: Causes, epidemiology, global consequences, and control. Ecol. Appl. 10: 689-710.

Marcel Rejmánek, (2000). Invasive plants: approaches and predictions. Austral Ecol. 25: 497-506

Memmott, J., S.V. Simon, Q. Paynter, A.W. Sheppard and P. Syrett, (2000). The invertebrate fauna on broom, Cystus scoparius, in two native and two exotic habitats. Acta Oecologia. 21: 213-222.

Mishra, A. (2013). Inhibitory effects of aqueous leaf extracts of Lantana camara on the growth of $P$. hysterophorous in fruiting stage. Asian J. Exp.

Sci. 27(2): 43-45

Mishra, A. (2014). Phytotoxic effect of Lantana camara leaf extract on germination and growth of Pisum sativum. Bot. 4(5): 55-56.

Nimbalkar, R.K., S.K. Chandekar and S.P. Khunte, (2011). Butterfly diversity in relation to nectar food plants from Bhor Tahsil, Pune District, Maharashtra, India. J. Threat. Taxa 3(3): 16011609.

Newsome, A. E., and I.R. Noble, (1986). Ecological and physiological characters of invading species. 1-21.

Gantayet, P.K., S.P. Adhikary, K.C. Lenka and B. Padhy, (2014). Allelopathic Impact of Lantana Camara on Vegetative Growth and Yield Components of Green Gram (Phaseolus radiatus) Int. J. Curr. Microbiol. App. Sci. 3(7): 327-335.

Pollard, E. (1977). A method for assessing changes in the abundance of butterflies. Biol. Conserv. 12: 115-134

Radosevich, S., J. Holt and C. Ghersa, (1997). Weed Ecology: Implications for Management. Second edition. New York: John Wiley and Sons, Inc. $589 \mathrm{p}$.

Ramesh Chander Kuhad, Rishi Gupta, Yogender Pal Khasa and Ajay Singh, (2010). Bioethanol production from Lantana camara (red sage): Pretreatment, saccharification and fermentation. 101(21): 8348-8354.

Rawat, Y.S., Y.D. Bhatt, P. Pande and S.P. Singh, (1994). Production and nutrient cycling in Arundinaria falcate and Lantana camara. The two converted ecosystems in Central Himalaya. Trop. Ecol. 35: 53-67.

Rice, E.L., (1984). In: Allelopathy. Second edition (Ed. E.L.Rice). Academic press. lando, Floride Pp: 422

Ridenour, W.M. and R.M. Callaway, (2001). The relative importance of allelopathy in interference: the effects of an invasive weed on a native bunchgrass. Oecologia, 126: 444-450.

Rodriguez L.F., (2006). Can Invasive Species Facilitate Native Species? Evidence of How, When, and Why These Impacts Occur. Biol. Inv. 8(4).pp 927-939 
Sankaran, K.V., T.A. Suresh and T.V. Sajeev, (2010). Indhyayile pradhana adhinivesa sasyangal: Jeevasastravum Niyanthranavum. Kerala Forest and Research Institute. 67P.

Sharma, O.M., P. Sharma, S. Pattabhi, V. Mahato, B.S. Sharma, (2007). A Review of the Hepatotoxic Plant Lantana camara. Crit. Rev. Toxicol. 37(4): 313352.

Shihan, T.R. and N. Kabir, (2015). Butterfly diversity in relation to Chromolaena odorata (L.) King and H.E. Robins as a nectar plant from two selected regions of Bangladesh. J. Entomol. Zool. Stud. 3(3): 258-264.

Tilman, D., C.L. Lehman and K.T. Thomas, (1997). Plant diversity and ecosystem productivity: Theoretical considerations. Proc. Nat. Acad. Sci. 94: 1857-1861.

Venner, M. (2006). Control of Invasive Species: A Synthesis of Highway Practice. National
Cooperative Highway Research Program Synthesis 363. Washington (DC): Transportation Research Board. $116 \mathrm{p}$

Wardle, D.A., K.S. Nicholson, M. Ahmed and A. Rahman, (1994). Interference effects of the invasive plant Carduus nutans L. against the nitrogen fixation ability of Trifolium repens $\mathrm{L}$. Pl. Soil 163: 287-297.

Waser, N.M., (1978a). Competition for hummingbird pollination and sequential flowering in two Colorado wildflowers. Ecol. 59: 934-944.

Weihe, P.E. and R.K. Neely, (1997). The effects of shading on competition between purple loosestrife and broadleaved cattail. Aqu. Bot. 59: 127-138.

Wynter-Blyth, M.A. (1957). Butterflies of Indian Region. Bombay Natural History Society, Bombay, 523pp. 